\title{
Effect of Temperature and Cathode Material on Power Production in an Earthenware Microbial Fuel Cell
}

\author{
Elvis Fosso-Kankeu*, Gerhard Rosslee, Soumya Pandit, Sadanand Pandey, Frans Waanders and \\ Sanette Marx
}

\begin{abstract}
This study investigates the performance of microbial fuel cells (MFCs) fed with municipal sewage water considering parameters such as temperature and cathode materials. Single chamber ceramic MFCs with the cathode exposed to water were used in this study. These MFCs were made from $\mathrm{M}^{+}$fine clay which were fired to create a ceramic pot. All four of the ceramics were placed in water, one at $19^{\circ} \mathrm{C}$ and the other three at $37^{\circ} \mathrm{C}$. Three ceramics, with different cathode materials, were exposed to water at $37^{\circ} \mathrm{C}$. The cathode materials investigated were clean ceramic, activated carbon and carbon black Vulcan XC-72 (Cabot Corporation). The activated carbon and carbon black Vulcan $\mathrm{XC}-72$ were fixed to the outside of the ceramic using polyvinyl alcohol (PVA) binder. The anode material was made of woven graphite fiber, the surface area of the anode was $136 \mathrm{~cm}^{2}$. Voltage readings were taken over a $1000 \Omega$ external resistance every 24 hours. Results indicate that $37^{\circ} \mathrm{C}$ is beneficial for power production. Investigation of cathode materials showed that the carbon black MFC produced the most power, $19.95 \mathrm{~mW} / \mathrm{m}^{2}$, followed by the activated carbon MFC with, $12.55 \mathrm{~mW} / \mathrm{m}^{2}$. The clean ceramic MFC produced $8.85 \mathrm{~mW} / \mathrm{m}^{2}$ of power. The activated carbon MFC performed best in terms of wastewater treating ability. The COD in the former MFC decreased with $37.57 \%$, followed by the carbon black MFC with, 34.46\%. The carbon black MFC had a CE of $44 \%$.

The use of MFC made of locally available clay material will allow to consider the possibility of sewage wastewater treatment with simultaneous generation of electricity.
\end{abstract}

Keywords-Activated carbon, Carbon black Vulcan XC-72, Ceramic, MFC, Water cathode, Woven graphite fiber

Manuscript received October 03, 2018. This work was supported in part by the National Research Foundation (NRF).

Elvis Fosso-Kankeu is with the Water Pollution Monitoring and Remediation Initiatives Research Group in the School of Chemical and Minerals Engineering of the North West University, Potchefstroom-South Africa.

Gerhard Rosslee is with the Water Pollution Monitoring and Remediation Initiatives Research Group in the School of Chemical and Minerals Engineering of the North West University, Potchefstroom-South Africa.

Frans Waanders is with the Water Pollution Monitoring and Remediation Initiatives Research Group in the School of Chemical and Minerals Engineering of the North West University, Potchefstroom-South Africa.

Sadanand Pandey is with the Water Pollution Monitoring and Remediation Initiatives Research Group in the School of Chemical and Minerals Engineering of the North West University, Potchefstroom-South Africa.

Sanette Marx is with the School of Chemical and Minerals Engineering of the North West University, Potchefstroom-South Africa.

Soumya Pandit is with the Amity Institute of Biotechnology, Amity University, Mumbai, India.

\section{INTRODUCTION}

Microbial fuel cells can produce power while treating wastewater. MFCs use bacteria to produce electrical current [1]. This is a growing bio-electrochemical technology which can transform the chemical energy contained in organic water pollutants into electricity whilst degrading the organic matters [2-9]; this technique can be used to restore usable water from wastewater, therefore providing opportunity to alleviate water crisis in a country such as South Africa which is considered water scarce [10-24] MFCs use the bacteria in the wastewater, which grow on the anode under anaerobic conditions, to produce protons and electrons. Microbes in the wastewater may contact the anode in different manners either by direct contact, nanowires or wirelessly. The electrons produced through the oxidation of organic matter are transferred to the electrodes by reparatory enzymes $[25 ; 26]$, the electrons are then transferred through an external resistance to the cathode [27]. Protons produced during the oxidation are transferred to the cathode via separators like cation exchangers [27]. The protons and electrons are accepted at the cathode by an electron acceptor, this completes the circuit and produces power [28; 29]. MFCs may also function differently depending on the type of inoculum.

Reactor type can be dependent on the type of inoculum, some MFCs treat soil [25; 30], urine [31], different types of wastewater and basically any biodegradable material. MFC designs have different variations, some include: duel chambered, single chambered and plant MFCs.

Conventional MFCs are dual chambered, which consists of a cathode, an anode and a proton exchange membrane (PEM) [3]. In a duel chambered MFC protons are transferred through the CEM from the anodic chamber to the cathodic chamber where the protons and electrons are accepted by oxygen. Cation exchange membranes (CEM) are used in MFCs as they are cheap and durable [32]. Similarly, the CEM can be replaced by a salt bridge, but the internal resistance is relatively high which causes low power output [33]. The membrane is, considered to be, the most important part of the MFC, the membrane should also be permeable to anions and cations produced at the anode [34].

Unglazed ceramic chambers have been implemented in recent studies and have shown great promise. The performance of the cell may benefit greatly from the type of chamber 
material, especially with ceramics as the clays used to produce the ceramic have different properties which may increase proton exchange through the ceramic. The efficiency of a MFC is primarily decided by the performance of the anode, this is due to important biochemical reactions taking place at the anode as well as the anode being a mediator for electron transfer [35].

A wide variety of electrode materials have been used in literature, each with advantages and disadvantages, most are also easily accessible. Graphite fiber has good electrical conductive properties and is resistant to oxidation which makes it well suitable for use in MFC. Carbon black Vulcan XC-72, also known as conductive black, shows great promise for an increased power production MFC. Carbon black Vulcan XC-72 and activated carbon are used as cathode materials which are fixed to the ceramic wall with a PVA binder. Bacterial growth and power production are both influenced by temperature.

This study will investigate the effect of temperature and cathode material on the wastewater treating ability and power production of the MFC.

\section{Methodology}

\section{A. Materials}

The ceramics were constructed from $\mathrm{M}^{+}$fine clay, which were fired to create the ceramics. Unglazed ceramics are porous which promotes proton transfer through the wall to the cathode. The inside diameter of the ceramic was $100 \mathrm{~mm}$ and the wall of the ceramic $5 \mathrm{~mm}$ thick. The height of the ceramics was $140 \mathrm{~mm}$.

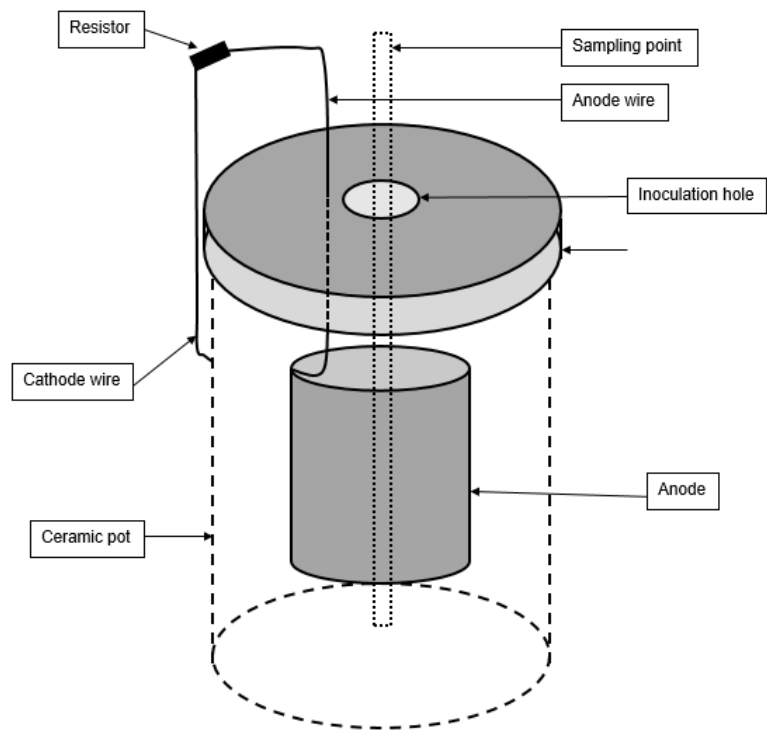

Fig 1: Ceramic MFC design

The graphite fiber (AMT Composites) anode was fixed to the inside of the anodic chamber to a PVC pipe. The anode had an area of $144 \mathrm{~cm}^{2}$.

The lids were constructed from PVC, a hole was drilled in the lid and tapped to be able to insert a plug. This made the task for inoculation easier. The plug was fitted with a sampling pipe which were sealed with a clamp. The lid was sealed to the ceramic by using marine silicone to ensure anaerobic conditions for the anode.
The MFCs were sealed prior to inoculation to ensure a tight seal. The cathode materials were activated carbon (ACE Chemicals), and carbon black Vulcan XC-72 (graciously offered by ORCHEM (Pty) Ltd in Durban, South Africa). The cathode materials were fixed to the outside of the ceramic using a PVA binder and a loading of $1.5 \mathrm{~g}$ cathode material to $10 \mathrm{~mL}$ of PVA. A $1000 \Omega$ resistor connected the anode compartment to the cathode compartment.

\section{B. Wastewater Characterization}

The raw wastewater was collected from the municipal sewer works, prior to any treatment. The wastewater was characterized by measuring the $\mathrm{pH}$, optical density and COD.

\section{Wastewater Preparation}

The $\mathrm{pH}$ of the water was measured and adjusted to a value of 7. To increase the $\mathrm{pH}$ a $0.1 \mathrm{M} \mathrm{NaOH}$ solution was used and to lower the $\mathrm{pH}$, a $0.1 \mathrm{M} \mathrm{H}_{2} \mathrm{SO}_{4}$ solution was used.

After $\mathrm{pH}$ adjustment the plug in the MFC lid were opened and the MFC was inoculated with $700 \mathrm{~mL}$ of the prepared wastewater. The anodic chamber was purged with nitrogen gas for 3 mins to remove oxygen.

\section{Setup}

Three of the reactors were placed in a water bath at $37^{\circ} \mathrm{C}$ and one were placed in water at $19^{\circ} \mathrm{C}$. The three MFCs in the waterbath were used to study the effect of cathode material on power production and water treating ability, while the two-clean cathode MFCs were, one at $19^{\circ} \mathrm{C}$ and the other at $37^{\circ} \mathrm{C}$, used to investigate the effect of temperature. The waterbath setup can be seen in Fig. 2.

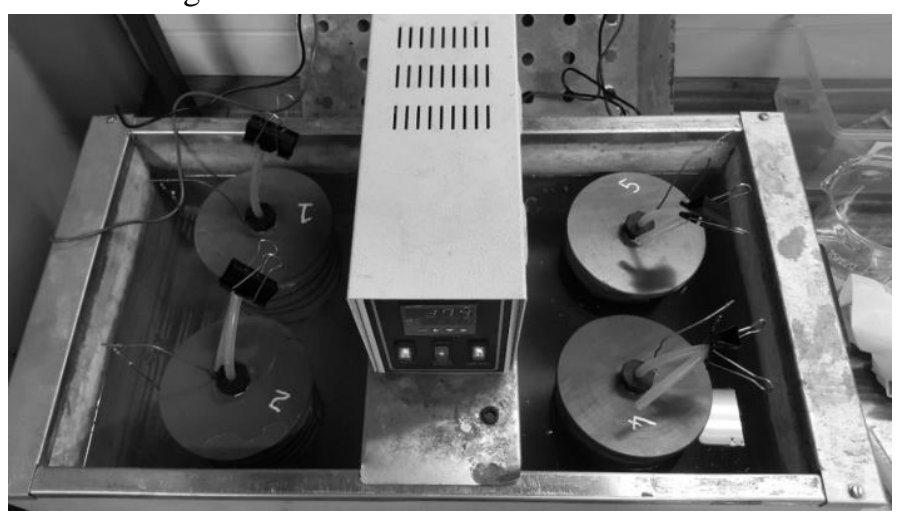

Fig 2: Waterbath setup

The cathode compartment of the MFC were exposed to air at all times.

\section{E. Current \& Voltage}

Current and voltage readings were taken every 24 hours. Three measurements were taken; the voltage over the external resistance, the current and the open current voltage. Current was calculated using relationship (1):

$$
I=\frac{V_{\text {Measured }}}{R_{\text {External }}}
$$

The power density is generally used to compare MFCs, the relationship used to calculate the power density is given in (2). 


$$
P=\frac{V^{2}}{A \times R}
$$

Where $\mathrm{V}$ is the measured potential over the external load, $\mathrm{R}$ is the magnitude of the external load in ohms and A is the anode surface area in square meters.

The Coulombic efficiency (CE) is a useful way to evaluate the performance of a MFC, this value indicates the ratio of the charge transported to the anode after bioelectro-oxidation of the inoculum. The CE can be calculated using relationship [34].

$$
C E=\frac{M \times I \times t}{F \times b \times V \times \Delta C O D}
$$

Where $\mathrm{M}$ is the molecular weight of oxygen, $32 \mathrm{~g} / \mathrm{mol}$; $\mathrm{I}$ is the produced current in $\mathrm{A}$; $\mathrm{t}$ is the run time of the MFC; $\mathrm{F}$ is Farradays constant, $96485 \mathrm{C} / \mathrm{mol}$; b is the amount of electrons exchanged per mole oxygen, which is 4 ; $\mathrm{V}$ is the volume of the innoculum; and $\triangle \mathrm{COD}$ is the change in COD over time t. The $\mathrm{CE}$ indicated the fraction of the innoculum used by bacteria for the production of current.

\section{F. Effluent Characterization}

The effluent was characterized by using the same methods as for the raw wastewater. The optical density was measured daily. After 7 days of operation the MFCs were emptied and cleaned using a $0.1 \mathrm{M} \mathrm{HCl}$ solution and rinsed with acetone and water.

\section{RESULTS \& DISCUSSION}

\section{A. Effect of temperature}

\section{1) Power production}

The OCV of the two, clean ceramic water cathode (CCWC), MFCs are compared in Fig. 3, the OCV of the $37^{\circ} \mathrm{C}$ MFC is 112 $\mathrm{mVs}$ higher than that of the $19^{\circ} \mathrm{C}$ MFC at day 7 .

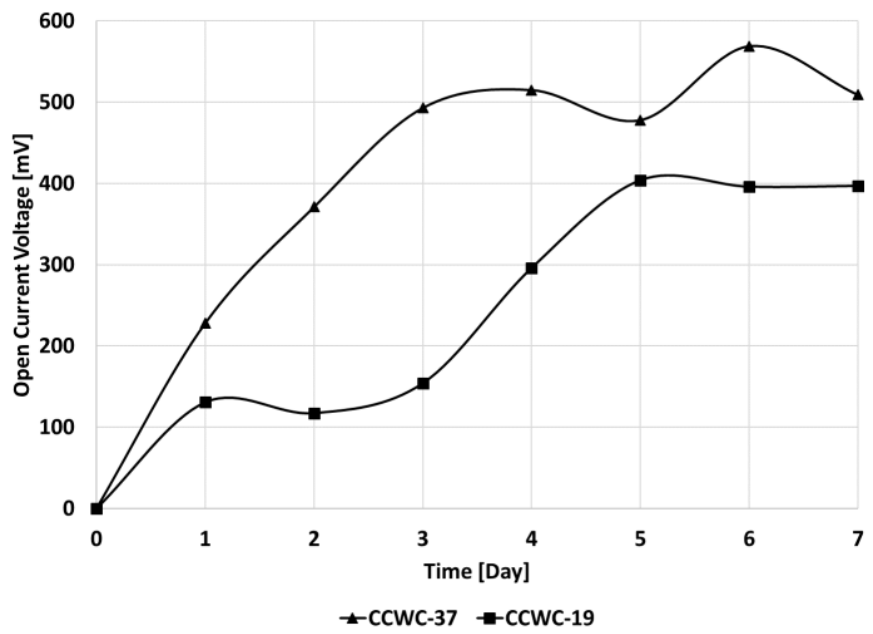

Fig 3: Open current voltage vs. Time

The potential of the MFC at $37^{\circ} \mathrm{C}$ peaked at a value of 0.359 $\mathrm{V}$ while the $19^{\circ} \mathrm{C}$ counterpart peaked at a value of $0.163 \mathrm{~V}$, on day 4 and 6 respectively. The potential of the $19^{\circ} \mathrm{C}$ MFC reached a steady state value at day 6 , whereas the $37^{\circ} \mathrm{C}$ MFC still showed deviation from a steady state value at day 7 . This result suggests that the higher temperature is beneficial for bacterial growth which is essential for electricity generation in the MFCs.

The difference between measured values, and consequently the trend of the cell potential and open current voltage of the $19^{\circ} \mathrm{C}$ MFC, indicates that ohmic losses occurred in the MFC.

The power production, a function of the cell voltage, external resistance and anode surface area, because the external resistance and anode surface area are constant in all the MFCs, the power production is dependent on the cell voltage of the respective MFCs. Consequently, the trend of the power density vs. time graph would be similar to that of the cell voltage.

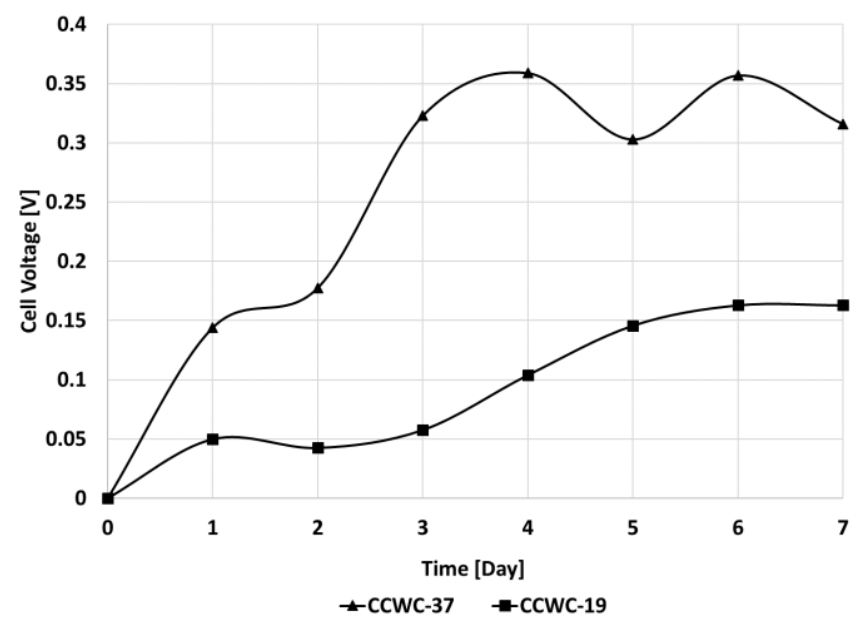

Fig 4: Cell voltage vs. Time

The power production in the $37^{\circ} \mathrm{C}$ MFC was higher than that of the $19^{\circ} \mathrm{C} \mathrm{MFC}$, the values peaked at $8.95 \mathrm{~mW} / \mathrm{m}^{2}$ on day 4 and $1.85 \mathrm{~mW} / \mathrm{m}^{2}$ on day 6 respectively. The higher temperature ensured a power increase of $385 \%$. Although the power of the $37^{\circ} \mathrm{C}$ MFC was much higher than that of the $19^{\circ} \mathrm{C}$ MFC, like the cell potential the $37^{\circ} \mathrm{C}$ MFC's power density was not stable, while the $19^{\circ} \mathrm{C}$ MFC had reached a steady state value at day 6 .

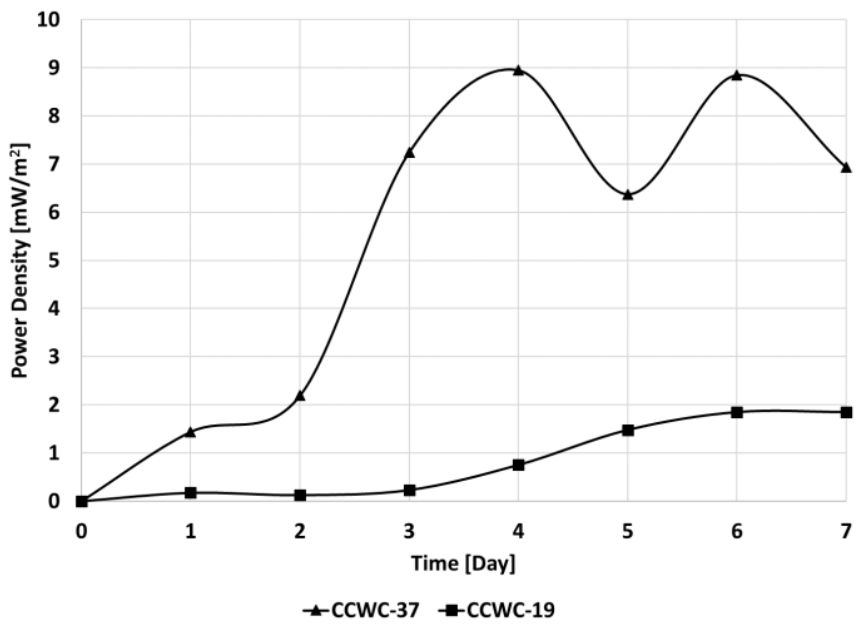

Fig 5: Power density vs. time

The Coulombic efficiency of the two reactors were calculated as $15 \%$ for the $19^{\circ} \mathrm{C}$ MFC and $32.45 \%$ for the $37^{\circ} \mathrm{C}$ MFC. These values state how effective the bacteria reduced the COD 
to produce a current. These values are consistent with the values of the power output in each reactor as well as the produced current.

\section{2) Water treating ability}

Biofilm growth was observed on the $37^{\circ} \mathrm{C}$ MFCs anode, while the $19^{\circ} \mathrm{C}$ MFC showed little signs of biofilm formation after 7 days of operation. This supports the higher power production in the $37^{\circ} \mathrm{C} \mathrm{MFC}$, because more bacteria is availible to consume the organic matter in the water to produce electrons.

The optical density in the wastewater decreaced over time. The initial value is $0.34 \mathrm{~A}$ while the value of the effluent from the $37^{\circ} \mathrm{C} \mathrm{MFC}$ and $19^{\circ} \mathrm{C} \mathrm{MFC}$ were, $0.106 \mathrm{~A}$ and $0.077 \mathrm{~A}$ respectively.

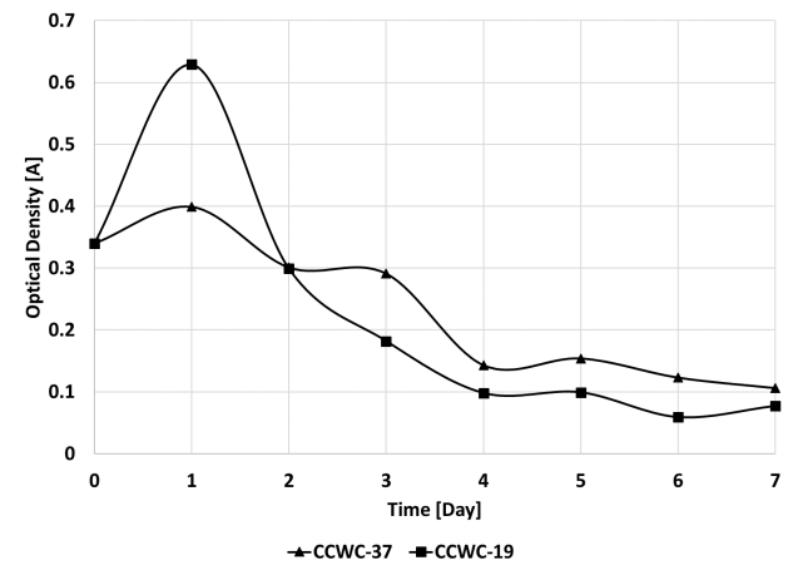

Fig 6: Optical density vs. time

The decrease of the optical density suggests that most of the bacteria contained within the water had migrated and attatched themselves to the anode or anodic wire. It is safe to assume that the baceria has migrated because, the MFCs showed an increace in electricity generation as the optical density lowered over the 7 days. The lower value of the $19^{\circ} \mathrm{C} \mathrm{MFC}$ is due to the slow growth rate of bacteria on the anode together with the simeltaneous death of bacteria in the water itself.

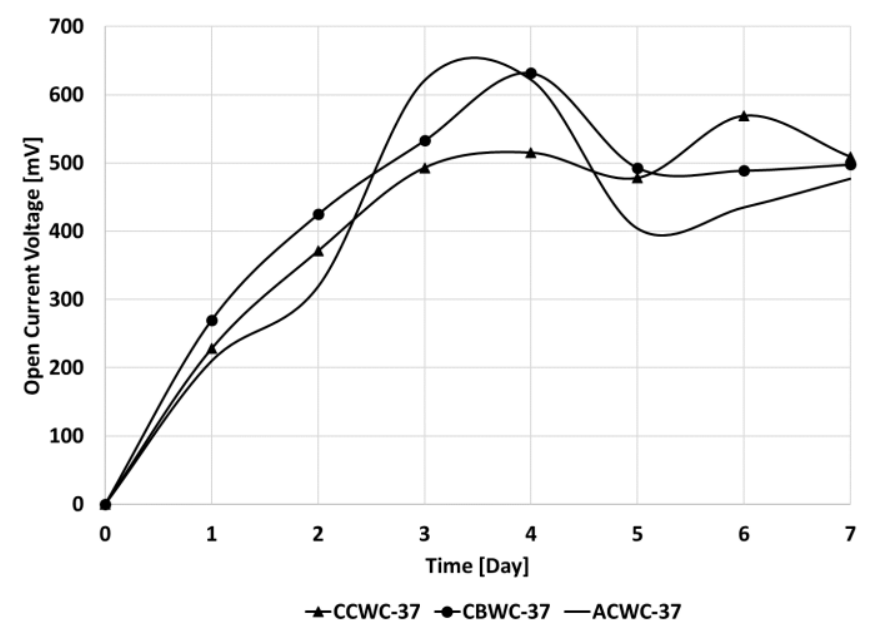

Fig 7: Open current voltage vs. Time
The COD treating ability of the ceramics at $37^{\circ} \mathrm{C}$ and $19^{\circ} \mathrm{C}$ are $33.4 \%$ and $7.2 \%$ respectively. The COD treating ability of the $37^{\circ} \mathrm{C}$ MFC is $13.3 \%$ higher than that of $19^{\circ} \mathrm{C} \mathrm{MFC}$. The initial $\mathrm{pH}$ values of the raw wastewater were adjusted to 7 before inoculation, the $\mathrm{pH}$ of the effluent in the $37^{\circ} \mathrm{C} \mathrm{MFC}$ and $19^{\circ} \mathrm{C}$ MFC was 6.57 and 6.73 respectively.

\section{B. Effect of cathode material}

\section{1) Power production}

Three MFCs; CCWC, carbon black water cathode (CBWC) and activated carbon water cathode (ACWC), were compared for these results, the experiment was carried out in a waterbath which kept the temperature constant at $37^{\circ} \mathrm{C}$ for 7 days. The first of the three MFCs was the clean ceramic cathode MFC, the second MFC was the carbon black Vulcan coated with a PVA binder, while the third MFC was the activated carbon coated with a PVA binder. The results show that the carbon black MFC performed best in terms of power production. The OCV values of all three the MFC are relatively close to one another as can be seen in Fig. 7, this suggests that the type of cathode material does not influence the OCV. The value of the OCV peaked on day 4 in the carbon black MFC at a value of $632 \mathrm{mV}$. The OCV

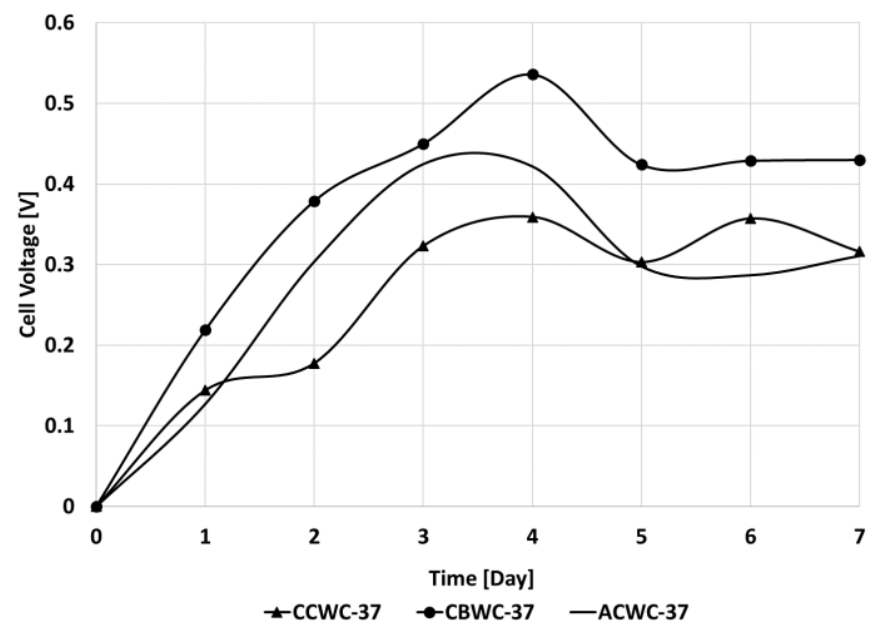

Fig 8: Cell voltage vs. Time

for the three MFCs at day 7 were $500 \mathrm{mV}$ with a standard deviation of $13.3 \mathrm{mV}$.

The peak cell potential between the three MFCs occurred on day 4 in the carbon black MFC and had a value of $0.536 \mathrm{~V}$. The activated carbon MFC followed the carbon black and peaked on day 3 at $0.425 \mathrm{~V}$, while the clean ceramic MFC peaked at day 4 at a value of $0.359 \mathrm{~V}$. This suggests that the carbon black, as cathode material, promoted the transport of protons from the anode chamber to the cathode chamber. The activated carbon MFC compared relatively well to the clean ceramic MFC, the clean ceramic MFC had a potential of $0.316 \mathrm{~V}$ on day 7 , while the activated carbon had a cell voltage of $0.311 \mathrm{~V}$. This suggests that the activated carbon applied to the ceramic using a PVA binder did not promote proton transfer through the wall of the ceramic. The cost of manufacturing the activated carbon MFC can be avoided and a clean ceramic MFC can rather be used to obtain relatively the same electricity generation ability. 
The power production follows the same trend as the cell voltage. The cell voltage peaked in the carbon black MFC on day 4 at a value of $19.95 \mathrm{~mW} / \mathrm{m}^{2}$ of anode, followed by the activated carbon MFC which peaked on day 3 at a value of $12.55 \mathrm{~mW} / \mathrm{m}^{2}$, whereas the clean ceramic MFC peaked on day 4 at a value of $8.95 \mathrm{~mW} / \mathrm{m}^{2}$.

As can be seen in Fig.9 the clean ceramic MFC and the activated carbon MFC had not yet reached a steady state value, while the power production of the carbon black MFC reached steady state on day 6 . The increased power is due to the improved proton transfer through the porous ceramic wall, to the carbon black cathode material. The activated carbon has shown to limit power production by inhibition of proton transfer through the ceramic membrane. Although, no cathode material is present in the clean ceramic membrane, this MFC performed more effectively than the activated carbon MFC on day 6 and 7 .

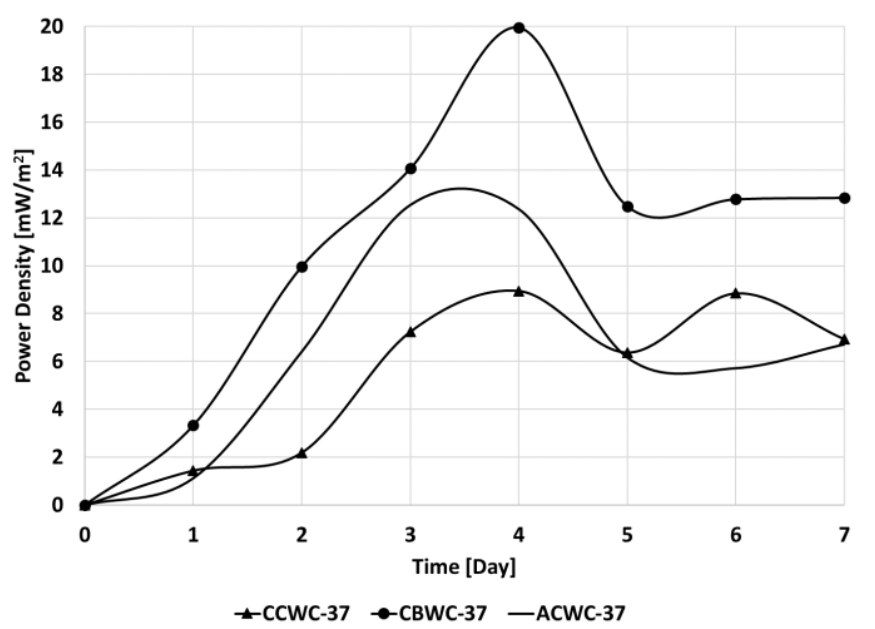

Fig 9: Power density vs. Time

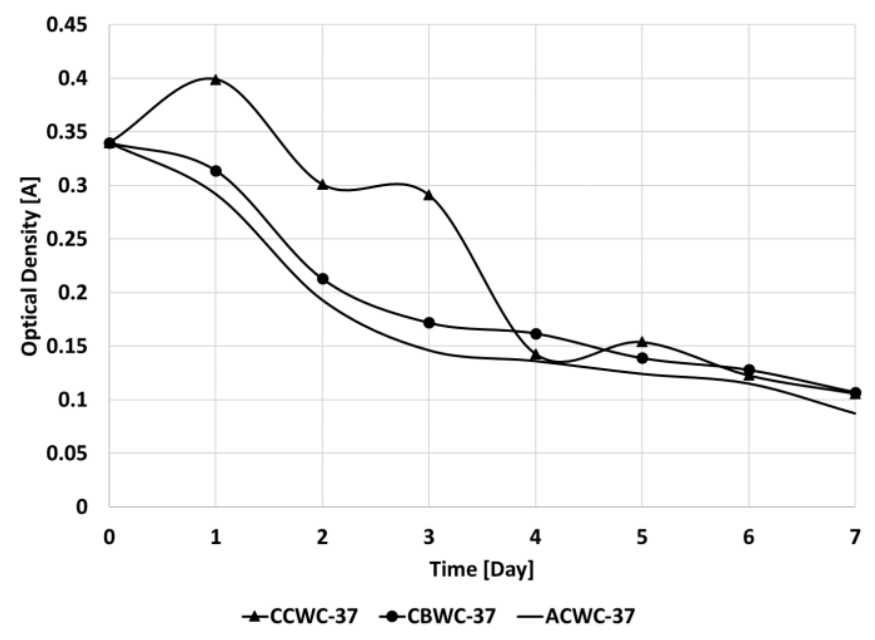

Fig 10: Optical density vs. Time
The Coulombic efficiency (CE) for the three reactors were calculated and the results were as follow; clean ceramic MFC had a CE of $32.45 \%$, the activated carbon MFC had a CE of $29.27 \%$, while the carbon black MFC had a CE of $44 \%$. The result indicates that in the carbon black MFC the bacteria converted the COD into current more effectively than in the other MFCs.

\section{2) Water treating ability}

All the MFCs that have been placed in the waterbath at $37^{\circ} \mathrm{C}$, had a thin biofilm layer on the anode and anodic wire. Keeping the temperature at this constant value has shown to increase power production in the clean ceramic MFCs, since bacteria in wastewater grow and perform more efficiently at this temperature.

As noted earlier, the optical density in all three reactors exposed to $37^{\circ} \mathrm{C}$ had decreased over 7 days. The initial value for the optical density was $0.34 \mathrm{~A}$, after 7 days of operation the optical density of the water inside the carbon black MFC, activated carbon MFC and the clean ceramic MFC were, 0.107 $\mathrm{A}, 0.087 \mathrm{~A}$ and $0.106 \mathrm{~A}$ respectively. The decrease in absorbance indicates that the organisms in the wastewater is either dying or migrating to adhere to the anode or anodic wire. The decrease of optical density and the increase of power production suggests that the latter is the probable cause of a decrease in the optical density.

The COD treating ability of the three reactors are as follows; the carbon black MFC treated $34.5 \%$ of the COD, the activated carbon treated $37.6 \%$ of the COD and the clean ceramic MFC treated $33.4 \%$ of the COD. The activated carbon MFC performed the best in terms of COD treating ability. The lower value of the optical density and the higher value of the COD treating ability in the activated carbon MFC, suggests that more bacteria adhered to the anode of this reactor. As a result, the treatment of organic matter increased. The COD treating ability of the carbon black MFC and clean ceramic MFC are relatively close, just like the optical densities of the two MFCs.

The $\mathrm{pH}$ in all three MFCs decreased over time from a value of 7 to, 6.32 in the carbon black MFC, 6.54 in the activated carbon MFC and 6.57 in the clean ceramic MFC.

\section{CONCLUSION}

The effect of temperature was tested with clean cathode ceramic MFCs, one at $19{ }^{\circ} \mathrm{C}$ and the other at $37^{\circ} \mathrm{C}$. The latter of the two MFCs performed the best in terms of power production reaching a peak value of $8.95 \mathrm{~mW} / \mathrm{m}^{2}$. The bacterial growth in the form of a dark biofilm could clearly be identified in the $37^{\circ} \mathrm{C}$ MFC. The $19^{\circ} \mathrm{C}$ MFC delivered a lower absorbance value in the water, this together with a low power production shows that the bacteria did not bind to the anode but rather died in the water. The effluent $\mathrm{pH}$ of the $19^{\circ} \mathrm{C}$ MFC was higher than the effluent $\mathrm{pH}$ of the $37^{\circ} \mathrm{C}$ MFC. Overall the $37^{\circ} \mathrm{MFC}$ showed better COD treating and power production.

For the $37{ }^{\circ} \mathrm{C}$ experiments, two different cathode materials were used, carbon black Vulcan XC-72 and activated carbon. The results of formerly mentioned cathode materials were compared to that of the clean cathode ceramic MFC. The results 
obtained showed that the carbon black MFC performed the best in terms of power production, delivering a peak value of 19.95 $\mathrm{mW} / \mathrm{m}^{2}$. The clean ceramic MFC and the activated carbon MFC produced nearly the same amount of power on day 7 . The optical density decreased the most in the activated carbon MFC, suggesting that most of the bacteria adhered to the surface of the anode. In contradiction with the high amount of bacteria on the anode, power production was not as high as the power generated by the carbon black MFC, which means that the activated carbon inhibited the transfer of protons through the ceramic wall. The $\mathrm{pH}$ of the carbon black MFC decreased the most followed by the activated carbon MFC. The activated carbon showed the best ability to treat the wastewater by decreasing the COD the most, by $37.6 \%$. The carbon black MFC had the highest CE, $44 \%$ which indicates the carbon black MFC had the best overall performance.

\section{ACKNOWLEDGMENT}

G. Rosslee is grateful and appreciates the assistance and guidance of Prof. E. Fosso-Kaneu, he is a remarkable study leader and certainly a great mentor.

\section{REFERENCES}

[1] Franks, A.E. \& Nevin, K.P. 2010. Microbial fuel cells, a current review. Energies, 3(5):899-919. https://doi.org/10.3390/en3050899

[2] Hernández-Flores, G., Poggi-Varaldo, H. \& Solorza-Feria, O. 2016. Comparison of alternative membranes to replace high cost Nafion ones in microbial fuel cells. International Journal of Hydrogen Energy, 41(48):23354-23362. https://doi.org/10.1016/j.ijhydene.2016.08.206

[3] Khalili, H.-B., Mohebbi-Kalhori, D. \& Afarani, M.S. 2017. Microbial fuel cell (MFC) using commercially available unglazed ceramic wares: Low-cost ceramic separators suitable for scale-up. International Journal of Hydrogen Energy, 42(12):8233-8241. https://doi.org/10.1016/j.ijhydene.2017.02.095

[4] Santoro, C., Artyushkova, K., Gajda, I., Babanova, S., Serov, A., Atanassov, P., Greenman, J., Colombo, A., Trasatti, S. \& Ieropoulos, I. 2015. Cathode materials for ceramic based microbial fuel cells (MFCs). International Journal of Hydrogen Energy, 40(42):14706-14715. https://doi.org/10.1016/j.ijhydene.2015.07.054

[5] E. Fosso-Kankeu, S. Marx, J.A. Ribberink, J.P.J. Van Den Bergh, Co-digestion of Sweet Sorghum Bagasse with Scientific and Crude Glycerols for Electricity Generation. $6^{\text {th }}$ International Conference on Green Technology, Renewable Energy and Environmental Engineering (ICGTREEE'2014). 27-28 November 2014, Cape Town-South Africa. (Award Winning Paper). Editors: Muzenda E. and Sandhu S. ISBN: 978-93-84468-08-8. Pp 265-270. 2014.

[6] E. Fosso-Kankeu, S. Marx, A. Meyer, Susceptibility of Saccharomyces cerevisiae to inhibitors and impact on bioethanol production yield. $6^{\text {th }}$ International Conference on Green Technology, Renewable Energy and Environmental Engineering (ICGTREEE'2014). 27-28 November 2014, Cape Town-South Africa. Editors: Muzenda E. and Sandhu S. ISBN: 978-93-84468-08-8. Pp 261-264. 2014.

[7] E. Fosso-Kankeu, S. Marx, A. Brink, Comparative adaptation of $B$. subtilis and $P$. aeruginosa in diesel supplemented medium and impact on biodegradation potential. $6^{\text {th }}$ International Conference on Green Technology, Renewable Energy and Environmental Engineering (ICGTREEE'2014). 27-28 November 2014, Cape Town-South Africa. Editors: Muzenda E. and Sandhu S. ISBN: 978-93-84468-08-8. Pp 253-256. 2014.

[8] E. Fosso-Kankeu, S. Marx, and C. Grobler, Simultaneous Gas and Electricity Production from an MFC Stimulated by Crude Glycerol. $7^{\text {th }}$ International Conference on Latest Trends in Engineering and Technology (ICLTET' 2015), November 26-27, 2015 Irene, Pretoria
(South Africa). Editors: E. Muzenda and T Yingthawornsuk. ISBN: 978-93-84422-58-5. 2015.

[9] E. Fosso-Kankeu, S. Marx, A. Brink, Adaptation behaviour of bacterial species and impact on the biodegradation of biodiesel-diesel. Brazilian Journal of Chemical Engineering. Vol. 34, no. 2, pp. 469-480, 2017. https://doi.org/10.1590/0104-6632.20170342s20150491

[10] E. Fosso-Kankeu, A.F. Mulaba-Bafubiandi, B.B. Mamba and T.G. Barnard, Prediction of metal-adsorption behaviour in the remediation of water contamination using indigenous microorganisms. Journal of Environmental Management. Vol. 92, no. 10, pp. 2786-2793, 2011. https://doi.org/10.1016/j.jenvman.2011.06.025

[11] H. Mittal, E. Fosso-Kankeu, Shivani B. Mishra, Ajay K. Mishra, Biosorption potential of Gum ghatti-g-poly (acrylic acid) and susceptibility to biodegradation by B. subtilis. International Journal of Biological Macromolecules. Vol. 62, pp. 370-378, 2013. https://doi.org/10.1016/j.ijbiomac.2013.09.023

[12] E. Fosso-Kankeu, A.F. Mulaba-Bafubiandi, T.G. Barnard, Establishing suitable conditions for metals recovery from metal saturated Bacillaceae bacterium using experimental design. International Biodeterioration and Biodegradation. Vol. 86, pp. 218-224, 2014. https://doi.org/10.1016/j.ibiod.2013.09.022

[13] E. Fosso-Kankeu, A.F. Mulaba-Bafubiandi and T.G. Barnard, Clayey materials in river basin enhancing microbialogical contamination of river water. Journal of Physics and Chemistry of the Earth. Vol. 67-69, pp. 236-241, 2014. https://doi.org/10.1016/j.pce.2013.10.001

[14] E. Fosso-Kankeu, A.F. Mulaba-Bafubiandi, Implication of plants and microbial metalloproteins in the bioremediation of polluted waters. Journal of Physics and Chemistry of the Earth. Vol. 67-69, 242-252, 2014. https://doi.org/10.1016/j.pce.2013.09.018

[15] E. Fosso-Kankeu, A.F. Mulaba-Bafubiandi, Challenges in the escalation of metal-biosorbing processes for water treatment: applied and commercialized technologies. African Journal of Biotechnology. Vol. 13, no. 17 , pp. 1756-1771, 2014. https://doi.org/10.5897/AJB2013.13311

[16] E. Fosso-Kankeu, F. Waanders, C. Fraser, Bentonite clay adsorption affinity for anionic and cationic dyes. $6^{\text {th }}$ International Conference on Green Technology, Renewable Energy and Environmental Engineering (ICGTREEE'2014). 27-28 November 2014, Cape Town-South Africa. Editors: Muzenda E. and Sandhu S. ISBN: 978-93-84468-08-8. Pp 257-260. Pp 257-260. 2014.

[17] E. Fosso-Kankeu, F. Waanders, and M. Geldenhuys, Photocatalytic Degradation of Dyes using $\mathrm{TiO}_{2}$ Nanoparticles of Different Shapes. $7^{\text {th }}$ International Conference on Latest Trends in Engineering and Technology (ICLTET' 2015), November 26-27, 2015 Irene, Pretoria (South Africa). Award Winning Paper. Editors: E. Muzenda and T Yingthawornsuk. ISBN: 978-93-84422-58-5. 2015.

[18] E. Fosso-Kankeu, F. Waanders, E. Maloy, Copolymerization of ethyl acrylate onto guar gum for the adsorption of $\mathrm{Mg}$ (II) and $\mathrm{Ca}$ (II) ions. Desalination and Water Treatment. doi: 10.1080/19443994.2016.1165147: pp. 1-10, 2016.

[19] E. Fosso-Kankeu, F. Waanders, C.L. Fourie, Adsorption of Congo Red by surfactant-impregnated bentonite clay. Desalination and Water Treatment. doi: 10.1080/19443994.2016.1177599: pp. 1-9, 2016.

[20] E. Fosso-Kankeu, H. Mittal, F. Waanders, S.S. Ray, Performance of synthesized hybrid hydrogel nanocomposite applied for the removal of metal ions from aqueous solutions. In: Drebenstedt, C. \& Paul, M.: IMWA 2016 - Mining Meets Water - Conflicts and Solutions. - p. 850 857; Freiberg/Germany (TU Bergakademie Freiberg). 2016.

[21] E. Fosso-Kankeu, F. Waanders, J. Potgieter, Enhanced adsorption capacity of sweet sorghum derived biochar towards malachite green dye using bentonite clay. International Conference on Advances in Science, Engineering, Technology and Natural Resources (ICASETNR-16) Nov. 24-25, 2016, Parys - South Africa. ISBN: 978-93-84468-79-8. 2016.

[22] E. Fosso-Kankeu, H. Mittal, F. Waanders, S.S. Ray, Thermodynamic properties and adsorption behaviour of hydrogel nanocomposites for cadmium removal from mine effluents. Journal of Industrial and Engineering Chemistry. Vol. 48, pp. 151-161, 2017. https://doi.org/10.1016/j.jiec.2016.12.033

[23] E. Fosso-Kankeu, F.B. Waanders, F.W. Steyn, Removal of Cr(VI) and $\mathrm{Zn}$ (II) from an aqueous solution using an organic-inorganic composite of 
bentonite-biochar-hematite. Desalination and Water Treatment. Vol. 59, pp. 144-153, 2017.

[24] L.P. Simelane, E. Fosso-Kankeu, P. Njobeh, S. Pandey, Response of bacterial biosorbents to chemical treatment as influenced by cell membrane structure and impact on the adsorption behaviour of dyes. Current Science. Vol. 114, no. 4, pp. 826-834, 2018. https://doi.org/10.18520/cs/v114/i04/826-834

[25] Fosso-Kankeu, E., Marx, S., Waanders, F. \& Jacobs, V. 2015. Impact of soil type on electricity generation from a Microbial Fuel Cell.

[26] Logan, B.E., Murano, C., Scott, K., Gray, N.D. \& Head, I.M. 2005. Electricity generation from cysteine in a microbial fuel cell. Water Research, 39(5):942-952. https://doi.org/10.1016/j.watres.2004.11.019

[27] Deval, A.S., Parikh, H.A., Kadier, A., Chandrasekhar, K., Bhagwat, A.M. \& Dikshit, A.K. 2017. Sequential microbial activities mediated bioelectricity production from distillery wastewater using bio-electrochemical system with simultaneous waste remediation. International Journal of Hydrogen Energy, 42(2):1130-1141. https://doi.org/10.1016/j.ijhydene.2016.11.114

[28] Logan, B.E. 2008. Microbial fuel cells: John Wiley \& Sons.

[29] Rabaey, K. \& Verstraete, W. 2005. Microbial fuel cells: novel biotechnology for energy generation. TRENDS in Biotechnology, 23(6):291-298.

https://doi.org/10.1016/j.tibtech.2005.04.008

[30] Regmi, R., Nitisoravut, R., Charoenroongtavee, S., Yimkhaophong, W. \& Phanthurat, O. 2018. Earthen Pot-Plant Microbial Fuel Cell Powered by Vetiver for Bioelectricity Production and Wastewater Treatment. CLEAN-Soil, Air, Water, 46(3):1700193. https://doi.org/10.1002/clen.201700193

[31] Barbosa, S.G., Peixoto, L., Soares, O.S.G.P., Pereira, M.F.R., Heijne, A.T., Kuntke, P., Alves, M.M. \& Pereira, M.A. 2018. Influence of carbon anode properties on performance and microbiome of Microbial Electrolysis Cells operated on urine. Electrochimica Acta, 267:122-132. https://doi.org/10.1016/j.electacta.2018.02.083

[32] Huang, L. \& Angelidaki, I. 2008. Effect of humic acids on electricity generation integrated with xylose degradation in microbial fuel cells. Biotechnology and bioengineering, 100(3):413-422. https://doi.org/10.1002/bit.21786

[33] Ieropoulos, I.A., Greenman, J., Melhuish, C. \& Hart, J. 2005. Comparative study of three types of microbial fuel cell. Enzyme and microbial technology, 37(2):238-245. https://doi.org/10.1016/j.enzmictec.2005.03.006

[34] Chatterjee, P. \& Ghangrekar, M. 2014a. Design of clayware separator-electrode assembly for treatment of wastewater in microbial fuel cells. Applied biochemistry and biotechnology, 173(2):378-390. https://doi.org/10.1007/s12010-014-0846-x

[35] Bhargavi, G., Venu, V. \& Renganathan, S. 2018. Microbial fuel cells: recent developments in design and materials. (In. IOP Conference Series: Materials Science and Engineering organised by: IOP Publishing. p. 012034).

https://doi.org/10.1088/1757-899X/330/1/012034

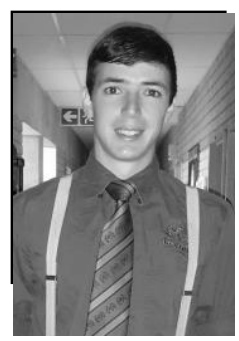

G. Rosslee was born in Rustenburg, South Africa on the $12^{\text {th }}$ of June 1995. Rosslee is a final year chemical engineering student of the 2018 class. Rosslee studied at the North West University in Potchefstroom.

He did vacation work as an operator assistant on a sewage treatment plant for 2 months. During his time at the sewage treatment plant he learned the process and plant operations. He completed a project on flocculation optimization on a dissolved air floatation 